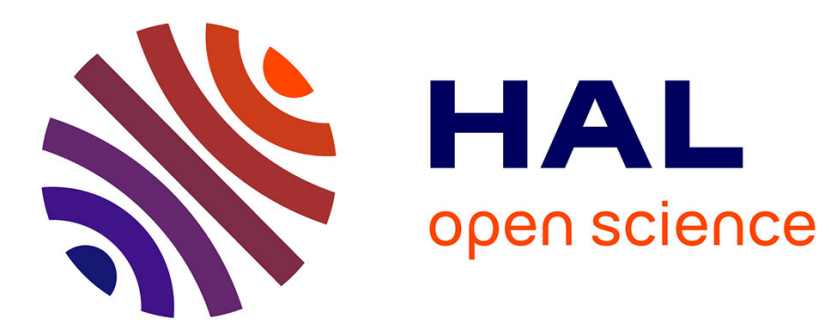

\title{
Beyond the Labour Income Tax Wedge: The Unemployment-Reducing Effect of Tax Progressivity
}

Etienne Lehmann, Claudio Lucifora, Simone Moriconi, Bruno van Der Linden

\section{To cite this version:}

Etienne Lehmann, Claudio Lucifora, Simone Moriconi, Bruno van Der Linden. Beyond the Labour Income Tax Wedge: The Unemployment-Reducing Effect of Tax Progressivity. 2013. halshs-00870050

\section{HAL Id: halshs-00870050 \\ https://shs.hal.science/halshs-00870050}

Preprint submitted on 8 Oct 2013

HAL is a multi-disciplinary open access archive for the deposit and dissemination of scientific research documents, whether they are published or not. The documents may come from teaching and research institutions in France or abroad, or from public or private research centers.
L'archive ouverte pluridisciplinaire HAL, est destinée au dépôt et à la diffusion de documents scientifiques de niveau recherche, publiés ou non, émanant des établissements d'enseignement et de recherche français ou étrangers, des laboratoires publics ou privés. 


\section{Beyond the Labour Income Tax Wedge: The Unemployment-Reducing Effect of Tax Progressivity}

ETIENNE LEHMANN, ClAUDiO LUCIFORA, SIMONE MORICONI, BRUNO VAN DER LINDEN

TEPP - Travail, Emploi et Politiques Publiques - FR CNRS 3126 


\title{
Beyond the Labour Income Tax Wedge: The Unemployment-Reducing Effect of Tax Progressivity*
}

\author{
Etienne LEHMANN ${ }^{\dagger}$ \\ CRED (TEPP) University Panthéon-Assas Paris 2 and CREST \\ Claudio LUCIFORA ${ }^{\ddagger}$ \\ Università Cattolica del Sacro Cuore and IZA \\ Simone MORICONI ${ }^{\S}$ \\ Università Cattolica del Sacro Cuore, Milano \\ Bruno VAN DER LINDEN \\ FNRS and IRES Université Catholique de Louvain
}

July 15, 2013

\begin{abstract}
This paper argues that, for a given overall level of labour income taxation, a more progressive tax schedule reduces the unemployment rate and increases the employment rate. From a theoretical point of view, higher progressivity induces a wage-moderation effect and increases overall employment since employment of low-paid workers is more responsive. We test these theoretical predictions on a panel of 21 OECD countries over 1998-2008. Controlling for the burden of taxation at the average wage, we show that a more progressive taxation reduces the unemployment rate and increases the employment rate. These findings are confirmed when we account for the potential endogeneity of both average taxation and progressivity. Overall our results suggest that policy-makers should not only focus on the detrimental effects of tax progressivity on in-work effort.
\end{abstract}

Keywords: Wage moderation, Employment, Taxation.

JEL Codes: E24, H22, J68

\footnotetext{
${ }^{*}$ We wish to thank participants at a seminars at CREST, TEPP Thematic School of Aussois and CESifo, with a particular mention to Pierre Cahuc, Clement Carbonnier, François Fontaine, Albrecht Glitz, Jean-Baptiste Michau, Marc-Andreas Muendler, Dana Rotz, Frederick van der Ploeg and Conny Wunsch for their valuable comments and suggestions. Usual caveats apply.

${ }^{\dagger}$ Email: etienne.lehmann@ensae.fr. Address: CREST, Timbre J360, 15 boulevard Gabriel Péri, 92245, Malakoff Cedex, France. Etienne Lehmann is also research fellow at IRES-Université Catholique de Louvain, IDEP, IZA and CESifo. Etienne Lehmann is also a junior member of IUF which is gratefully acknowledged for its financial support.

${ }^{\ddagger}$ Email: claudio.lucifora@unicatt.it Address: Università Cattolica del Sacro Cuore, Department of Economics and Finance - Largo Gemelli, 1 - 20123 Milano, Italy. Claudio Lucifora is also research fellow at IZA.

${ }^{\S}$ Email: simone.moriconi@unicatt.it. Address: Università Cattolica del Sacro Cuore, Department of Economics and Finance - Largo Gemelli, 1 - 20123 Milano, Italy. Simone Moriconi is also research fellow at University of Luxembourg, CREA.

`Email: bruno.vanderlinden@uclouvain.be. Address: IRES, Université Catholique de Louvain, Place Montesquieu 3, B1348, Louvain-la-Neuve, Belgium. Bruno Van der Linden is also research fellow at IZA, CESifo. Part of this research was conducted while Bruno Van der Linden was visiting CRED, Université Paris PanthéonAssas.
} 